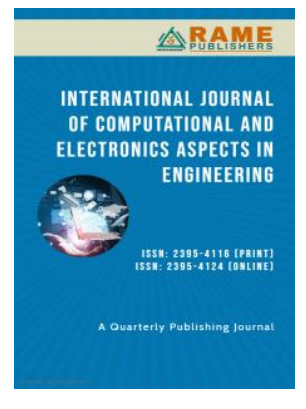

Rohini Pochhi rohinipochhi@gmail.com

Rakhi Chede rakhichede08@gmail.com

Sandeep Thakare sandeepthakare@gmail.com

Department of Electronics \& Communication, Tulshiramji Gaikwad Patil College of Engineering \& Technology, Nagpur, India

\title{
Design and Development of Solar Powered Compost Bin - A Review
}

\begin{abstract}
Due to the waste generated in any country or in our India, various problems such as about pollution or about human's health are arrived. And we know that the amount of waste generation is widely increased day by day. For that it should be necessary to manage the waste in any way. So, there are various methods for management of waste. And the better one is composting at houses. Everyone should have to know about composting, because of which wastes can be properly managed. The compost bin with some new way and new idea is introduced by 'Design and Development of Solar Powered Compost Bin'. This system makes it user friendly, maintenance free and nature friendly with the help of solar energy which is cost effective also. The process of composting is done with an organic waste which are biodegradable wastes that are generally produced by kitchen wastes, solid wastes etc. The approach of this project is to manage the waste with new technologies and knowledge of composting.
\end{abstract}

Keywords - composting, compost bin, solar energy, biodegradable, organic wastes, technologies

\section{INTRODUCTION}

It is necessary to do proper waste management. There are various methods for waste management to refuse disposal waste such as we can refuse disposal waste by open dump, incineration, ocean and river dumping deepwell injection, sanitary landfills, animal feeding g, and composting $[1,2]$. Out of these various methods, the composting is the best method and it can be done in a proper way at household level or community level also. Now the question is how the composting can be done and what type of wastes can be composted? For that it should need to know the types of wastes. There are different types of wastes. One of them is solid wastes which is largely produced every day in our country [3,4]. The solid waste contains organic wastes as well as inorganic

Review Article

First Online on - 30 March 2021

(C) 2021 RAME Publishers

This is an open access article under the CC BY 4.0 International License https://creativecommons.org/licenses/by/4.0/

Cite this article - Rohini Pochhi, Rakhi Chede, Sandeep Thakare, "Design and Development of Solar Powered Compost Bin - A Review", International Journal of Computational and Electronic Aspects in Engineering, RAME Publishers, vol. 2, issue 2, pp. 1-5, 2021.

https://doi.org/10.26706/ijceae.2.1.20210303 wastes. So, the separation that means segregation of an organic wastes and an inorganic waste plays an important role to manage the solid waste $[5,6]$. By segregating these wastes, it will become very easy for further process. In solid wastes, the amount of an organic waste is greater in comparison with an inorganic waste $[7,8]$. So, an organic waste can be recycled and used to make compost of it and an inorganic waste can be collected and stored in better way [9]. An organic waste which can be composted includes an industrial wastes like food, paper and pulp, yard and garden wastes, kitchen wastes like fruits, teabag, peelings, sand, egg shell etc [10]. Hence, with proper organic waste management, the amount of affects and the problems arriving from this waste like pollution or effects on human's health will be definitely reduced in better manner [11].

The process of degradation of an organic degradable material is called composting [12]. The composting is the better and safe process and method for management of waste as compared to other conventional waste management methods like open dump, ocean dumping, animal feeding etc [13,14]. Composting is the best process of decomposition. Composting is done by 
recycling an organic waste and convert it into useful products. Increase of waste can be controlled by management of organic waste with the composting method [15,16]. Also, an organic waste can be further categorized into three that are municipal solid waste, kitchen waste and agriculture waste [17]. Composting of an organic waste produces compost which can be used as a fertilizer [18]. Many companies are already working on composting, but there are various targets and factors to maintain and achieve and every time it is not possible to achieve them at community level or an industrial level [19]. So, if we start to segregate the wastes like dry waste and wet waste separately by making separate dust bins for it and start to compost the biodegradable wastes at our houses and at household level, then it will help to reduce the amount of waste [20]. Some sensors can be used with composting such as temperature sensor, moisture sensor and humidity sensor etc. for controlling parameters like temperature, moisture and humidity also [21]. Usually, composting process or compost bins are worked with electricity which becomes more costly and it requires high maintenance also and bad odor problem also arrive through this [22]. For that, this proposed system is the best to overcome all these problems, which will be worked on solar powered supply. Compost bins are very useful to manage waste in better way and at household level, which is basically just great and best way to reduce the amount of waste [23]. There are various advantages of making compost from the wastes, that are composting improves the structure as well as fertility of the soil which is best for agriculture applications, an environment becomes healthy as management of waste through composting reduces waste [24].

\section{Methodology}

Flow chart for process of composting is shown in figure 1 .

\section{A. Waste Detection}

Input waste is pushed into the proposed system through inlet. The process of detection of the waste is done using sensors like IR proximity sensor and starts the system. The metal detection system is also used to detect the metallic waste.

\section{B. Waste Classification}

After detection of the waste, waste is classified or distinguish between dry waste, wet waste and metallic waste separately. So, the classification of the waste is done according to waste detection.

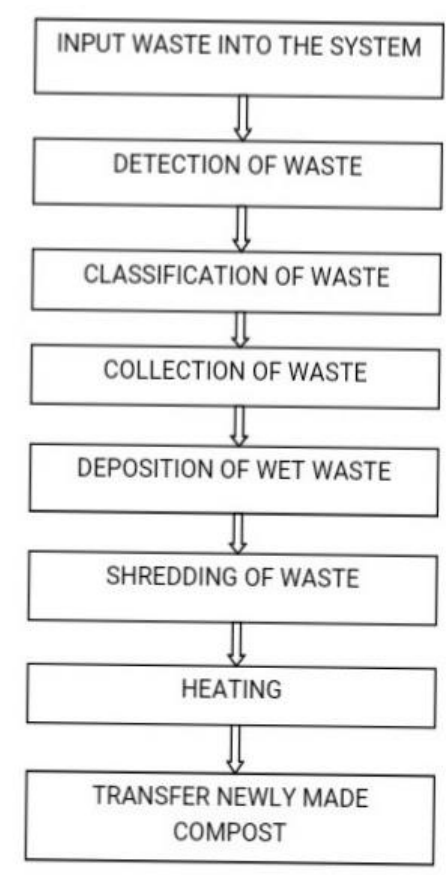

Figure 1. Flow chart for process of Composting [25,26].

\section{Waste Collection}

According to the classification of the waste, wastes are collected separately into separate containers. Separate collection of the waste is very important for further processing directly.

\section{Waste Deposition}

The wet waste like vegetables waste, egg shells, food waste, peels etc. are deposited in the shredder for composting.

\section{E. Waste Shredding}

The process of shredding is done in the shredder. The shredding of the waste means mixing of the waste into small pieces. All the wet wastes are applied to the shredder and shred it into the tiny particles. 


\section{F. Heating}

The shredded waste that is tiny particles of that wet waste is then transferred into a heated chamber. In this heated chamber, tiny particles rotates and wastes are then mixed with some sawdust. It removes moisture from that waste and also prevents it from bad odor. This heated chamber is totally worked on solar powered supply and the mixture of this waste is heated with the help of solar energy. This mixture needs to keep in this chamber for around two days.

\section{G. Transfer of Compost}

The newly made compost after two days from the heated chamber will get, which will be then transferred to any storage container or it may be storage rack for cooling it for near about seven to eight days.

\section{Methods OF CoMPosting}

\section{A. In-Vessel Composting}

Composting by this method is dependent on mechanical technique and some forced aeration. This method is very helpful to enhance composting process.

\section{B. Vermicomposting}

To degrade an organic waste, an earthworm is used in this method. An earthworm can eat weight per day. This method is useful to improve the fertility of the soil.

\section{Windrow Composting}

In this method, raw materials are used in long narrow windrows which are regularly turned. By using this method of composting, composting is done rapidly, but it is quite difficult and its cost is also high.

\section{Sheet Composting}

In this composting method, organic materials are decayed. Organic materials are spread into the soil directly. This method is cost effective and simple in use.

\section{E. Indian Indore Composting}

The mixture of raw materials is made into a layer by layer within a week. To wet the waste water is sprinkled over the raw material and after near about one month, the compost is made. So, this method is time consuming method.

\section{F. Indian Bangalore Composting}

The composting of night soil and reuse it is recommended in this method. And by digging trenches where night soil is put in alternate layers. In this way composting is done in this method. As this method of composting is invented at Bangalore, it is called as 'Indian Bangalore Composting'.

\section{G. Static Composting}

In this method, wastes are composted using aeration like static aerations etc. In comparison with all other composting methods this method is a simple method, easy to use and cost effective also. But the degradation of an organic waste is slow, as an aeration is mainly dependent on movement of air via the pile.

\section{H. Berkley Rapid Composting}

In this method, composting of the waste is done faster as compared to other composting methods. It means it is a faster and rapid composting method. It is important to chop the hard tissues for enhancing decomposition and there is no need to chop soft tissues, as they decompose easily and fast [27-29].

\section{CONCLUSION}

It is best to use safe waste management method which is nothing but the composting instead of improper and unsafe waste management. The compost bins with composting process at household levels plays a very important role to reduce the volume of the waste. The segregation also can be better for best results with composting. As the generation of the waste is increased rapidly day by day and to overcome the problems of improper waste management, the composting and segregation is explained with some new and innovative techniques or ideas. The compost bins which worked with solar energy obviously reduces its cost and save money as well as electricity also. The composting can be 
done with various methods which are mentioned. Composting also provides original fertilizer in agriculture applications instead of chemical fertilizers. And in this way, it is possible to use freshly made compost which becomes very beneficial to replenish the soil and also helps to make environment clean.

\section{REFERENCES}

[1] Neha Mahuli, Madulika G., G. Manikandraja, H. Sarmah, Shubham A. And K. Christopher 2020, International Conference on Advances in Mechanical Engineering 912042010.

[2] Aeslina Abdul Kadir, Nur Wahidah Azhari and Siti Noratifah Jamaludin 2016, MATEC Web of Conferences 47, 05025.

[3] Saleh Ali Tweib, Rakmi Abd Rahman and Mohd Sahaid Kalil 2011, International Conference on Environment and Industrial Innovation IPCBEE.

[4] Modupe Stella Ayilara, Oluwaseyi Samuel Olanrewaju, Olubukola Oluranti Babalola and Olu Odeyemi 2020, 'Waste Management through Composting: Challenges and Potentials' Sustainability 2020,12,4456.

[5] Dr. K M. Tajne, Swarda Dixit, Prasad B., Satyam S., Ankit L., Madhuri M. - "Smart Compost Bin", , International Journal of Innovations in Enginering and Science, Vol 4 No. 8, 2019.

[6] Mr. Jobin F., Mr Melbin TL, Praveen CN, ''Solar Power Smart Waste Bin" - International Journal of Computer Engineering in Research Trends, Vol 2, Issue 12, December 2015, pp. 1083-1086.

[7] Jake D. La Madrid, Jennifer C. Dela Cruz, Joyco B. Lucero, Allen M. Paz, "Solar Powered Automatic Leaf Shredder for Vermicomposting", IEEE International Conference on Humanoid, Nanotechnology, Information Technology, Communication \& Control, Environment and Management, 2017.

[8] C. Vinothini, Tharini M, Saranya Sasikumar G, Karthick R Ikash K, "IoT Based Smart Garbage System Powered with Solar Cell”, International Journal of Engineering and Technical Research, V9.

[9] Aaron U. Aquino, Dustin G. Baylon, Francis Paul B. Dela Cruz, "Development of a Solar Powered Closed-Loop Vermicomposting System with Automatic Monitoring and Correction Via IoT and Raspberry Pi Module", IEEE International Conference on Humanoid, Nanotechnology,
Information Technology, Communication and Control, Environment and Management, 2019.

[10] Matthew Aberman, Cody Baker, Shayna Brock, Thomas Phan, "Automatic Aerobic Composting Machine". Available at https://www.ece.ucf.edu/seniordesign/sp2016fa2016/g17/d ocs/SD1\%20Report.pdf

[11] Kellow Pardini, Joel J. P. C. Rodrigues, Sergei A. Kozlov, Neeraj Kumar and Vasco Furtado, "IoT Based Solid Waste Management Solutions: A Survey”, Journal of Sensor and Actuator Networks, January 2019.

[12] Craig Somerton, A Solar Heated Worm Compost Bin, American Society for Engineering Education, 2009.

[13] Priyanka Lokhande, Himank Jain, Rijo Rajan, Pratiksha Kini, Tushar Chaudhari, "Automatic Waste Food Composting Using Solar Energy", International Journal of Creative Research Thoughts, 2018.

[14] Ripath Jahan, M. G. Jhansi Rani, U. L. N. Manasa, G. Susmitha, M. K. Girija, P. Nikhitha, "Automated Waste Segregation System using IoT”, International Research Journal of Engineering \& Technology, April 2020.

[15] Sachin Jayaprakash, Lohit HS and Abhilash BS, "Design and Development of Compost Bin for Indian Kitchen", International Journal of Waste Resources, 2018.

[16] Barbara Pleasant, Deborah Martin, "The Complete Compost Gardening Guide", North Adams, Massachusetts: Storey Publishing, 2008.

[17] Nick Noyes, "Easy Composters You Can Build" Storey Country Wisdom Bulletin, January 10, 1995.

[18] Stu Campbell, “Let It Rot! : The Gardener's Guide to Composting”, Storey's Down-To-Earth Guides, Jan 3, 1998.

[19] Grace Gershuny, "Start with the Soil: The Organic Gardener's Guide to Improving Soil for Higher Yields, More Beautiful Flowers and a Healthy, Easy Care Garden”, June 1, 1993.

[20] John H. Pierce, "Home Solar Gardening Solar Greenhouses for Your House, Backyard or Apartment”, 1992.

[21] Banu L, Madhumitha, Menaka, Revathi, "Solar Powered Smart Garbage Can for Waste Segregation”, International Journal of Engineering Science \& Computing, 2019.

[22] Oree Vishwamitra, Veeneet Anand Maudhoo, “A Microcontroller based Household Anaerobic Food Digester", Smart Instrumentation Management \& Application, 2015. 
[23] Amar Cholkar, Shivanand Birdar, Praveen Mogre, Sangamesh Chidre, "Automated Solar Powered Mini Waste Segregation Plant".

[24] Nithika Sailesh, Vikas Shinde, "Home Composter: Domestic use Composter", World Congress on Sustainable Technologies IEEE Conference, 2015.

[25] Nasrin B. Pansari, S. B. Deosarkar, A. B. Nandgaonkar, "Smart Compost System", Second International Conference on ent Computing \& Control Systems, 2018.

[26] Gopi Karelia, “Thane Engineers Innovate Composting Unit That Is 50\% Cheaper \& Runs on Solar Power", The Better India, April 22, 2020. [Accessed on 20 ${ }^{\text {th }}$ June 2021]. Available at-

https://www.thebetterindia.com/224385/maharashtraengineers-innovate-solar-composting-waste-managementcheap-environment-india-gop $94 /$

[27] Reducing the Impact of Wasted Food by Feeding the Soil and Composting, Environmental Protection Agency (EPA).
[Accessed on 20 $0^{\text {th }}$ June 2021]. Available athttps://www.epa.gov/sustainable-managementfood/reducing-impact-wasted-food-feeding-soil-andcomposting

[28] Composting in your backyard, Minnesota Pollution Control Agency [Accessed on 20 $0^{\text {th }}$ June 2021]. Available at -https://www.pca.state.mn.us/waste/composting-yourbackyard

[29] Robert L. Spencer, Solar Power at Composting Facilities, BioCycle, Vol. 50, No. 9, p. 32, September 2009. [Accessed on 20 ${ }^{\text {th }}$ June 2021]. Available at https://www.biocycle.net/solar-power-at-compostingfacilities 